\title{
Pop-up Ads and Behaviour Patterns: A Quantitative Analysis Involving Perception of Saudi Users
}

\author{
Alaa Hanbazazh ${ }^{1,2} \&$ Dr Carlton Reeve ${ }^{2}$ \\ ${ }^{1}$ Faculty of Communication \& Media, Department of Marketing Communication, King Abdul-Aziz University, \\ Jeddah, Saudi Arabia \\ ${ }^{2}$ Department of Media Design \& Technology, Bradford University, Bradford, UK \\ Correspondence: Alaa Hanbazazah, King Abdulaziz University, Jeddah, Saudi arabia Department of Marketing \\ Communication, King Abdulaziz University, Jeddah, Saudi arabia. 9666952000. E-mail: \\ ashanbazazah@kau.edu.sa
}

Received: October 1, 2021

Accepted: November 2, $2021 \quad$ Online Published: November 12, 2021

doi:10.5539/ijms.v13n4p31

URL: https://doi.org/10.5539/ijms.v13n4p31

\begin{abstract}
The study aimed to investigate consumer behaviour towards pop-up ads. The study is quantitative in nature and carries out a survey questionnaire. The study sample consisted of 100 active users of social media (i.e., Snapchat, Instagram, Twitter, Tik Tok and gaming application). The data collected were analysed using Statistical Package of Social Sciences (SPSS) version 23.0. Moreover, the study used descriptive statistical analyses, a t-test was used to check the different impact of independent variables and finally ANOVA test was used to find the impact of more than one independent variable on the dependent one. The results of the study showed that Snapchat $(30.47 \%)$ was the widely used application among the participants and an average user consumes social media more than 4 hours a day which makes it $40 \%$ of the participants. The study also found that participants disagreed that they always look for pop-up ads $(\mathrm{M}=1.71, \mathrm{Std}=0.92)$. Also, the study found no significant difference in perceptions of respondents towards pop-up ads with regard to gender. The ANOVA test revealed that educational level (0.627) didn't show any significant difference towards the opinions of participants about pop-up ads whereas, age level (0.50) and monthly income (0.001) showed significant difference towards the opinions of participants about pop-up ads. The study concluded that pop-up ads do not actually impact consumer behaviour positively and are not the affective means of attracting consumers.
\end{abstract}

Keywords: advertisements, pop-ups, social media and consumer behaviour

\section{Introduction}

With the development of the technological era in the recent past, between 2000 to 2019, there has been an increase of $1104 \%$ people having assessing to the internet (Katuwandeniya \& Abeywardana, 2019), which have resulted in the rapid growth in the number of Internet users for multitude purposes, social contact, shopping, and entertainment activities. In response, traditional advertisers are shifting to online advertisement (Snyder \& Garcia-Garcia, 2016). This promotional tool delivers advertising messages to the masses by using a variety of media platforms. Before the emergence of the internet, firms used traditional advertising mediums such as television, radio, or newspaper to reach the target audience, spread awareness to the public about their products, and increase sales. In 2016 US alone, have reached around US\$72.5 billion in web advertising revenue, which exceeds magazines, yellow pages, cable TV, and radio advertising revenue, placing the web advertisements second after TV advertisements (IAB, 2017). Modern-day technology advancement has enabled modern channels and platforms for advertising, such as website advertising, email advertising, mobile advertising, and SMS advertising (Le \& Vo, 2017). Online advertisement can be done in various ways, and these ways are constantly evolving (Chiu et al., 2017)

Among the various online advertisement strategies, pop-up ads or pop-ups are form of online advertising, which is a small window that suddenly appears (pops up) in the visual interface used to advertise when a site or application is opened, where the user clicks or scrolls with the mouse, a window appears containing an offer of some product or service in the visual interface. A study by Winder (2007) investigated the impact of pop-up ads on customer behavior. The pop-up advertisement has tended to show a higher rate of intent to purchase when compared to the typical banner advertisements (Cho et al., 2011). However, Edward et al. (2002) argue that 
many online users perceive pop-up advertisements as annoying and irritating. Even though pop-up advertising is associated with greater levels of consumer attention and a higher click through rate, it also can result in negative consumer attitudes due to their invasiveness (Le \& Vo 2017). The reason why a number of people find the pop-up advertisements irritating is because of how they tend to interrupt the users' website activity. Garter (2012) conducted a study where he revealed that when compared to other forms of internet advertising, many consumers considered pop-up ads the most irritating. However, from the advertiser's perspective, irritating ads are not always negative (Winder, 2007). The vast majority of advertisers will use pop-up ads because of the direct impact on the customer for appearing right in their face (Dillabough, 2012). However, some advertisers have responded to the numerous complaints by consumers regarding the intrusive nature of these pop-up ads. Among such interventions is creating the functionality to close the pop-up, Artificial Intelligence (AI) to determine the moments the user is online to pass the time and not necessarily being focused on a specific goal (Edwards et al., 2012).

Another strategy employed to make the ads less irritating is tailoring them to improve customer value. According to Lenhart and Madden (2017), pop-up ads are found less irritating when they present more value to the customers. Despite all the efforts made by advertisement agencies to make pop-up ads more attractive, the consumers still view them as disturbing and irritating. It happens to be a scapegoat for people who have no liking for advertisements. Moreover, consumer attitudes and beliefs concerning online advertising varied in different countries (Wang \& Sun, 2010). However, most of the research was carried out in developed economies, such as the United States or the United Kingdom, where advertising technologies are evolved, and consumers have different attitudes toward internet advertising and are more experienced with e-commerce. As a result, it's important to investigate the phenomenon in other developing countries, such as Saudi Arabia's emerging markets, in terms of internet users. According to Kemp (2021), the number of internet users in Saudi Arabia increased by 1.3 million (4.2\%) between 2020 and 2021, while the number of social media users in Saudi Arabia increased by 2.1 million $(8.0 \%)$.

Furthermore, most previous research talks about the effectiveness of pop-up ads compared to traditional advertisements and explores pop-ads effectiveness in online gaming. Therefore, there is a need to understand consumer perception about pop-up ads and why they think of them as good or bad. Hence, this study aims to investigate the perception of active Saudi users of social media platforms about pop-up ads. The study contributes towards the designing of online advertisements. The reason for an ad to be ineffective for online users is due to its obstructive format. Advertisers and marketers can make pop-up ads useful by improving their effectiveness. Pop-up ads effectiveness is achieved by making pop-up ads so that it provides valuable information to the consumers rather than irritating or disturbing them.

\section{Literature Review}

\subsection{Pop-up Advertisements}

Pop up advertisements have seemingly always been a part of the Internet user experience, and they have been well researched since their inception in the late 1990s. They now exist on many types of websites, including online gaming and news. Pop-up advertisements were very influential in the early days of internet advertisement. However, now many good internet browsers such as Google Chrome have gotten fairly advanced at blocking these ads (Susil, 2018). However, the designers of these JavaScript pop-up windows continuously evolve the technology to place advertisement copy, image, and video in front of the user's eye (Zuckerman, 2014). The literature on pop-up windows runs the gamut from studying the efficacy of pop-up ads to studying consumer behaviour regarding them to gauging how long-term exposure to pop up ads affects individual consumers. The following summarizes the main points, arguments, and findings from recent research on the topic:

One of the main aims of research on pop-up ads is to study how effective they drive or influence consumer behaviour. A recent case study on undergraduate students of the Co-operative University of Kenya revealed that $46.68 \%$ of people clicked pop-up ads sometimes and $30.26 \%$ of people often liked the pop-ads; however, the percentage of getting influenced by the ads was deficient, only $3.95 \%$. The study states that users are highly affected by these ads, while $9.21 \%$ of the respondents were influenced but only to some extent (Purity \& Paul, 2021). Even though the pop-up ads have greater attention and click-through rate of internet users, they can also lead to the negative attitude of consumers due to its interference in the task of the user of a website. For instance, internet users reported that pop-up ads are more interfering than the other form of advertisement while web browsing (Kariyawasam \& Wigley, 2017). There are many internet or online advertisements, including banners, skyscrapers, pop-ups, interstitials, wallpaper, and floating. The pop-up ads are the most common sense of anger and annoyance (Harms et al., 2019; Kariyawasam \& Wigley, 2017). 
Furthermore, another study reported a negative attitude of the consumer towards the pop-up ads compared to the other six advertising formats. (Liu et al., 2019). However, people who have a negative attitude towards pop-ups do not usually have negative thoughts about the brands whose pop-up ads are shown. According to Purity and Paul (2021) study, out of a sample of 76 respondents, only 2 people liked pop-ups, and 40 people intensely disliked the pop-up ads. Compared to the majority that dislikes pop-ups, fewer people disliked brands that use pop-ups, with only 21 people strongly disliking the brands. In addition, Le and Vo (2017), in a comparative study on consumer attitude towards different advertisement formats, ANOVA test was conducted to know the attitudinal score of other forms with all Wikis' Lambda scores were significant $(\mathrm{p}<0.05)$. The respondent considered banners and in-line ads more entertaining than pop-up ads. Moreover, the respondent considers pop-up ads as least informative than the in-line ads, and the number one rank was for banner ads. In contrast, when it comes to irritating attitudinal, the number one ranked was for pop-up than in-line followed banner, which was the lowest of the three ad formats.

Another popular branch of research on pop up ads is the effect on users exposed to pop up ads. A very recent study by Abbasi et al. (2021) looks into the impact of advertising value in online gaming and their effect on online gamers. It also shows how the presence of advertising may affect gamers experiences. Their study found that the perceived value of the advertised entity could negatively or positively affect a user's experience. For example, when high-end luxury brands were shown, gamers tended to feel more inspired to play, while low-end brands and pop-up advertising was likely to have the opposite effect. In addition, Purity and Paul (2021) findings regarding the influence of pop-ups on consumer purchase behaviour showed that pop-ups highly influence only $3.95 \%$ of respondents while $9.21 \%$ were influenced but to a small extent.

In contrast, the majority said that they are not influenced. Vincent and Ni (2020) showed that pop-up ads had an insignificant and adverse effect on a consumer's buying decisions. If pop-up ads increase, the buying decision will decrease, but it is not significant. Pop-up ads also have a negative effect and significant on consumer purchase intention, which means that if pop-ups increase, the purchase intention decreases, and it is significant. Moreover, there is significant and positive purchase intention on buying decisions; therefore, if purchase intention increases, it will also increase the buying decisions. In addition to this, pop-up ads have a negative effect on buying decisions through purchase intention, which therefore means that purchase intention mediates the effect of pop-up ads in significantly increasing or decreasing buying.

Courbet et al. (2014) completed research on how pop-up ads, and web advertising in general, affect Internet users in the long term. The pop-ups are usually viewed at a low level of attention and generally remembered only implicitly. They found that exposure to this type of advertisement in the long term could affect internet user task completion and cognitive function, suggesting that they are a negative force for both learning and work environments. A recent experimental study shows that if 20s delay pop-up ads than immediately appearing on the website, the fixation length and count are higher for the delayed pop-ups (Hsieh et al., 2020).

The third branch of research on pop up ads concerns how to make the ads work in the most effective way for the advertiser. Hsieh et al. (2020) found that pop up ads that do not appear right away on a web page are more effective and that advertisers and programmers should likely program pop-ups to wait at least five seconds before popping up to have the greatest effect. It is also reported that there is a negative correlation between perceived intrusiveness and browsing behaviour towards pop-up ads. Those are the ads that appear after the browsers have had a chance to read the page's main content with lower perceived intrusiveness and higher browsing; these ads are also viewed for a longer time.

According to Chatterjee (2016), the ads placed on the websites and other online digital media are designed to divert the consumer's attention from their active browsing to processing the information in the advertisements. When the ads and the brand are promoted, they have a higher degree of personal relevance and high involvement by the consumer. Previous studies showed a higher degree of motivation, opportunity and the ability to attend to the ads, make central ad processing, and proceed to click to get more information from the target ad (Cho, 2019). This has been found to create communication outcomes and a memory that lasts for a longer duration of time.

Within the ordinary context of browsing over the website, pop-up ads take the format of deliberate exposure and constantly compete with the embedded ads and the web pages' editorial content (Janiszewski, 2018). Given the fact that the attention of the consumers is primarily focused on the attainment of their navigational objectives, the banner ads are ignored by the consumers because of how the ads lie in the visual field's periphery; or there is a cognitive push to naturally avoid them (Dreze \& Hussherr, 2018). It is further suggested by Dreze and Hussherr (2018) that the eyes of the consumers are subconsciously trained to avoid the nabber advertisements in what is called "banner ads blindness". For this reason, the pop-up ads have been designed so that their 
appearance on the web pages has low levels of involvement, and their peripheral cues like their size and appearance always induce customers to click on them (Cho, 2019).

The pop-up ads have been shown by prior research as the form of online digital marketing that yields the highest level of advertisement perception, a higher rate of clicking, and a higher persuasion to purchasing among consumers (Cho, 2019). This implies that the measures are based on explicit memory like recognition and recall are high. This translates into a direct transfer of the effect from the ad viewed to the brand being advertised (Cho, 2019). The retention of the ad, the site content is lesser in pop-up ads compared to in-line ads because the action of click on the closing button distracts the user attention for the content, and it's also there for a shorter time. With the development of the technological era in the recent past, between 2000 to 2019, there has been an increase of $1104 \%$ people having assessing to the internet (Katuwandeniya \& Abeywardana, 2019), which have resulted in the rapid growth in the number of Internet users for multitude purposes, social contact, shopping, and entertainment activities. In response, traditional advertisers are shifting to online advertisement (Snyder \& Garcia-Garcia, 2016). This promotional tool delivers advertising messages to the masses by using a variety of media platforms. Before the emergence of the internet, firms used traditional advertising mediums such as television, radio, or newspaper to reach the target audience, spread awareness to the public about their products, and increase sales. In 2016 US alone, have reached around US\$72.5 billion in web advertising revenue, which exceeds magazines, yellow pages, cable TV, and radio advertising revenue, placing the web advertisements second after TV advertisements (IAB, 2017). Modern-day technology advancement has enabled modern channels and platforms for advertising, such as website advertising, email advertising, mobile advertising, and SMS advertising (Le \& Vo, 2017). Online advertisement can be done in various ways, and these ways are constantly evolving (Chiu et al., 2017)

Among the various online advertisement strategies, pop-up ads or pop-ups are form of online advertising, which is a small window that suddenly appears (pops up) in the visual interface used to advertise when a site or application is opened, where the user clicks or scrolls with the mouse, a window appears containing an offer of some product or service in the visual interface. A study by Winder (2007) investigated the impact of pop-up ads on customer behavior. The pop-up advertisement has tended to show a higher rate of intent to purchase when compared to the typical banner advertisements (Cho et al., 2011). However, Edward et al. (2002) argue that many online users perceive pop-up advertisements as annoying and irritating. Even though pop-up advertising is associated with greater levels of consumer attention and a higher click through rate, it also can result in negative consumer attitudes due to their invasiveness (Le \& Vo 2017). The reason why a number of people find the pop-up advertisements irritating is because of how they tend to interrupt the users' website activity. Garter (2012) conducted a study where he revealed that when compared to other forms of internet advertising, many consumers considered pop-up ads the most irritating. However, from the advertiser's perspective, irritating ads are not always negative (Winder, 2007). The vast majority of advertisers will use pop-up ads because of the direct impact on the customer for appearing right in their face (Dillabough, 2012). However, some advertisers have responded to the numerous complaints by consumers regarding the intrusive nature of these pop-up ads. Among such interventions is creating the functionality to close the pop-up, Artificial Intelligence (AI) to determine the moments the user is online to pass the time and not necessarily being focused on a specific goal (Edwards et al., 2012).

Another strategy employed to make the ads less irritating is tailoring them to improve customer value. According to Lenhart and Madden (2017), pop-up ads are found less irritating when they present more value to the customers. Despite all the efforts made by advertisement agencies to make pop-up ads more attractive, the consumers still view them as disturbing and irritating. It happens to be a scapegoat for people who have no liking for advertisements. Moreover, consumer attitudes and beliefs concerning online advertising varied in different countries (Wang \& Sun, 2010). However, most of the research was carried out in developed economies, such as the United States or the United Kingdom, where advertising technologies are evolved, and consumers have different attitudes toward internet advertising and are more experienced with e-commerce. As a result, it's important to investigate the phenomenon in other developing countries, such as Saudi Arabia's emerging markets, in terms of internet users. According to Kemp (2021), the number of internet users in Saudi Arabia increased by 1.3 million (4.2\%) between 2020 and 2021, while the number of social media users in Saudi Arabia increased by 2.1 million $(8.0 \%)$.

Furthermore, most previous research talks about the effectiveness of pop-up ads compared to traditional advertisements and explores pop-ads effectiveness in online gaming. Therefore, there is a need to understand consumer perception about pop-up ads and why they think of them as good or bad. Hence, this study aims to investigate the perception of active Saudi users of social media platforms about pop-up ads. The study 
contributes towards the designing of online advertisements. The reason for an ad to be ineffective for online users is due to its obstructive format. Advertisers and marketers can make pop-up ads useful by improving their effectiveness. Pop-up ads effectiveness is achieved by making pop-up ads so that it provides valuable information to the consumers rather than irritating or disturbing them.

\subsection{Gender Impact on Pop-up Ads}

A study of 200 young working females was conducted to determine the impact of pop-ups on their purchasing behaviour when accessing the internet to raise awareness and develop perceptions. The association between these factors was determined using correlation and regression analysis. Because there is a positive relationship between consumer awareness and consumer perceptions, the consumer will be motivated to acquire a specific product (Longani, 2018). Furthermore, a study by Krushali et al. (2021) examines the views of different genders on pop-up advertising, revealing that females are more interested in observing the beneficial effects of pop-up ads than males. The majority of female respondents stated they appreciated it because it allowed them to compare prices and know if a product was available during off-seasons. As a result, the efficacy of commercials would be increased if marketers used more tailored ads and targeted a female audience. Furthermore, a study found that pop-up adverts irritate both men and women (Keem \& Lee, 2018).

Thus, there is a need to investigate the impact of gender on the participant's opinion about the pop-up ads in Saudi Arabia

$\mathbf{H}_{\mathbf{1}}$ : Gender impacts the participant's opinion about pop-up ads.

\subsection{Age and Educational Level Impact on Pop-up Ads}

A study by Makinen (2019) on younger people showed that user-generated ads are more trustworthy sources than the ads generated by the companies themselves. Another study conducted in Sri Lanka on young adults relieved that youth perceptions towards pop-up and pre-roll advertisements are not satisfactory as they often do not access the information provided by the pop-up ads and skip pre-roll ads (Thilina, Guruge, \& Nanayakkara, 2020). Furthermore, according to Chaffey (2020), 31 per cent of youth aged 16 to 24 years discover brands/products through social media ads, which is the most significant number compared to other age groups in the 16-64-year range as well as the global rate of 27 per cent. According to a study conducted among bachelor students at a Kenyan institution, 76.1 per cent of teenagers are not influenced by Facebook adverts. In contrast, only 23.9 per cent said that Facebook ads have a significant influence on them. When asked what material had the most impact on their purchasing choice, 42.9 per cent of respondents said trending topics, whereas only 25.7 per cent of the vote went to advertisements and visuals (Maina, 2021).

In addition, Chi (2011) observed in his study that the college-aged population has a good attitude toward social media and social media marketing. For example, college-aged people often give a product a higher rating if its marketing is visible online across social media networks. Cox (2010) also looked into the relationship between consumer attitudes about social media marketing and the age of the consumers. According to the author, attitudes and perceptions about the use of social media in marketing (blogs, vlogs, and brand channels) vary with age. Users between the ages of 18 and 25 are more likely to engage in digital marketing through blogs, vlogs, and short clips videos, according to her and users between the ages of 35 and 54, on the other hand, like essential movies and more postings that are less difficult and easy to read. On the other hand, both groups are against invasive ad formats that keep interfering with users' intended activity while on social media.

Thus, there is a need to investigate the impact of age and education on the participant's opinion about the pop-up ads in Saudi Arabia.

$\mathbf{H}_{2}$ : Age impacts the participants opinion about pop-up ads.

$\mathbf{H}_{3}$ : Educational level impacts the participants opinion about pop-up ads.

\subsection{Monthly Income Impact on Pop-up Ads}

People who are employed are more interested in web ads than those who are unemployed. Mostly, people who earn more than $\$ 30,001$ each month use web ads (Varghese \& Chitra, 2020). Another study aimed to determine how online advertising influences buyers' purchasing behaviour from Poland and the United Kingdom-based on their income levels. Consumers in both nations were hesitant to invest in advertising that had to be seen before or during the viewing of the target films and the so-called pop-up ads (Szalonka, Sadowa, Wicka, \& Wicki, 2020).

Thus, there is a need to investigate the impact of monthly income on the participant's opinion about the pop-up ads in Saudi Arabia.

$\mathbf{H}_{4}$ : Monthly income impacts the participants opinion about pop-up ads. 


\section{Methodology}

\subsection{Study Design and Sample}

The study adopted a quantitative research methodology therefore, a survey was conducted on 100 active users of social media (i.e., Snapchat, Instagram, Twitter, Tik Tok, gaming application) in Saudi. The study participants were selected through random sampling technique. The study distributed 134 questionnaires via Google forms and out of them received 120 forms. The study excluded 20 forms as they were incomplete and therefore only 100 completely filled questionnaires were included in the study. According to Raosoft the recommended sample size was 100 with $95 \%$ confidence level and $5 \%$ margin of error. The sample consisted of male and female participants both. Before the commencement of the study, the researcher explained the purpose of the study and obtained a written consent form from the all the participants.

\subsection{Data Collection}

A survey questionnaire was developed for data collection. The questionnaire was divided into three parts. The first part consisted of demographic questions. The second part was on respondents use of social media applications and the last part consist of their perceptions about pop-up ads and its impact on their behaviour. Moreover, the questionnaire was designed on a 5-Point Likert scale with 1) Strongly Disagree, 2) Disagree, 3) Neither agree nor Disagree (Neutral), 4) Agree, 5) Strongly agree.

\subsection{Data Analysis}

The collected data were analysed using Statistical Package of Social Sciences (SPSS) version 23.0. Furthermore, the study analysed the data by using descriptive analysis by providing mean and standard deviation values. Moreover, T-test was used to identify if gender had any impact on their opinion about pop-up ads. ANOVA test was used to find out the impact of 3 factors educational level, age group and monthly income on participants opinion about pop-up ads.

\section{Results}

Table 1 shows the demographic profile of the survey respondents. Majority of the participants are females which makes up $80 \%$ of the sample size and remaining $20 \%$ are the male respondents of the study. Most of the participants are aged between 36-55 years (45\%), followed by 18-25years (20\%) and 19\% were over 55years and lastly a small percentage was between 26-35 years (16\%). Majority of the participants hold their Master's degree $(30 \%)$, hold Secondary degree (24\%), Bachelor degree (13\%), and only $6 \%$ hold $\mathrm{PhD}$. Most participants have a monthly income of more than 10,000 Saudi riyal/month (33\%), however $(30 \%)$ didn't have any source of income, (19\%) earn around from 6,100-10,000 Saudi riyal/month, (16\%) earn around 4,000 to 6,000 Saudi riyal/month.

Table 1. Demographic details of the participants

\begin{tabular}{lll}
\hline Gender & $\mathbf{n}$ & Percent \\
Males & 20 & $20 \%$ \\
Females & 80 & $80 \%$ \\
Age Group & $\mathbf{n}$ & Percent \\
$18-25$ years & 20 & $20 \%$ \\
$26-35$ years & 16 & $16 \%$ \\
$36-55$ years & 45 & $45 \%$ \\
Over 55 years & 19 & $19 \%$ \\
Educational Level & $\mathbf{n}$ & Percent \\
Secondary & 24 & $24 \%$ \\
Bachelor & 13 & $13 \%$ \\
Masters & 30 & $30 \%$ \\
PhD & 6 & $6 \%$ \\
Other & 27 & $27 \%$ \\
Monthly Income & $\mathbf{n}$ & Percent \\
Nothing & 30 & $30 \%$ \\
$4000-6000$ & 16 & $16 \%$ \\
$6100-10000$ & 19 & $19 \%$ \\
More than 10000 & 33 & $33 \%$ \\
Other & 2 & $2 \%$ \\
\hline
\end{tabular}


Table 2 shows the commonly used applications among the respondents. The widely used application is Snapchat that is $(30.47 \%)$, followed by use Instagram (28.91\%), use Tik Tok that is (12.50\%), use Gaming Applications is $(10.16 \%)$, and $(4.69 \%)$ use Twitter.

Table 2. Commonly used applications (Multiple Response)

\begin{tabular}{llll}
\hline Application & n & Percent & Percent of Cases \\
\hline Snapchat & 78 & $30.47 \%$ & $78 \%$ \\
Instagram & 74 & $28.91 \%$ & $74 \%$ \\
Tik Tok & 32 & $12.50 \%$ & $32 \%$ \\
Gaming Application & 26 & $10.16 \%$ & $26 \%$ \\
Twitter & 12 & $4.69 \%$ & $12 \%$ \\
Other & 34 & $13.28 \%$ & $34 \%$ \\
Total & $\mathbf{2 5 6}$ & $\mathbf{1 0 0 \%}$ & $\mathbf{2 5 6 \%}$ \\
\hline
\end{tabular}

Table 3 shows the amount of time spend per day on above mentioned applications which shows that most of them spend more than four hours a day (40\%), whereas two hours and three hours per day $(21 \%)$, and only $18 \%$ spend one hour a day.

Table 3. Time spent in front of apps/day

\begin{tabular}{lll}
\hline Time & n & Percent \\
\hline One Hour & 18 & $18 \%$ \\
Two Hours & 21 & $21 \%$ \\
Three Hours & 21 & $21 \%$ \\
More than Four Hours & 40 & $40 \%$ \\
\hline
\end{tabular}

Table 4 illustrates the perceptions of pop-up ads and its impact on participants behaviour. The statement it is possible to buy a product from the pop-up ads' rank 1 with $M=3.02$, St. Deviation $=1.14$, statement 'the content that appears in the ad is very attractive' rank 2 with $M=2.74$, St. Deviation $=1.12$, statement 'top Brands that popup ads recommend more than other brands' rank 3 with $M=2.59$, St. Deviation $=1.16$, statement 'the level of ads that pop up from the apps meet my needs and expectations' rank 4 with $M=2.51$, St. Deviation $=1.09$, statement 'I generally recommend products or services from pop-up ads' with rank 5 with $M=2.34$, St. Deviation $=1.02$, statement 'I find the pop-up ads fun' rank 6 with $M=2.18$, St. Deviation $=1.09$, statement 'I am satisfied with the pop-up ads on social media' rank 7 with $M=2.01$, St. Deviation $=0.88$, statement 'trust products that advertise in pop-up ads' rank 8 with $M=1.99$, St. Deviation $=0.82$, statement 'I always look for a way to keep pop-up ads' rank 9 with $M=1.71$, St. Deviation $=0.92$.

Table 4. Perceptions of popup adds and its impact on their behavior

\begin{tabular}{lllll}
\hline Statement & Mean & Std. & Rank & Trend \\
\hline I find the pop-up ads fun & 2.18 & 1.09 & 6 & Disagree \\
I always look for a way to keep pop-up ads & 1.71 & 0.92 & 9 & Strongly Disagree \\
The content that appears in the ad is very attractive & 2.74 & 1.12 & 2 & Neutral \\
I am satisfied with the pop-up ads on social media & 2.01 & 0.88 & 7 & Disagree \\
The level of ads that pop up from the apps meet my needs and expectations & 2.51 & 1.09 & 4 & Disagree \\
Top brands that popup ads recommend more than other brands & 2.59 & 1.16 & 3 & Disagree \\
Trust products that advertise in pop-up ads & 1.99 & 0.82 & 8 & Disagree \\
It is possible to buy a product from the pop-up ads & 3.02 & 1.14 & 1 & Neutral \\
I generally recommend products or services from pop-up ads & 2.34 & 1.02 & 5 & Disagree \\
\hline
\end{tabular}

Note. Pimentel, J. L. (2010). A note on the usage of Likert Scaling for research data analysis. USM R\&D Journal, 18(2), 109-112.

Table 5 shows the t-test of gender as an independent variable. The results in the table reflects that gender does not have any significant difference in the perceptions of pop-up ads of the respondents. As the significant value was higher $(0.665)$ than the recommended $P$-value $<0.05$. 
Table 5. Independent sample T-test

Note. Significant at the 0.05 level.

\begin{tabular}{lllll}
\hline Factor & $\mathbf{t}$ & df & Sig. & Mean difference \\
\hline Gender & -.452 & 28.317 & .655 & -.08889 \\
\hline
\end{tabular}

Table 6 is the ANOVA test which was carried out to find out the effect of 3 independent variables such as educational level, age group and monthly income on one independent variable that is consumer behaviour. The results in the table shows that educational level variable does not have any significant difference on the perceptions of the respondents towards pop-up ads as the $p$ value was higher $(0.627)$ than the recommended rage $<0.05$ whereas age group (0.05) and monthly income (0.001) did have a significant difference on the respondents' perception towards pop-up ads as the $p$ value was within the recommended range of $p<0.05$

Table 6. ANOVA

\begin{tabular}{lllllll}
\hline Factor & & Sum of Squares & df & Mean Square & F & Sig. \\
\hline Educational Level & Between Groups & 1.540 & 4 & .385 & .652 & .627 \\
& Within Groups & 56.117 & 95 & .591 & & \\
& Total & 57.657 & 99 & & & .050 \\
Age Group & Between Groups & 4.496 & 3 & 1.499 & 2.706 & \\
& Within Groups & 53.160 & 96 & .554 & & .001 \\
Monthly Income & Total & 57.657 & 99 & & 5.095 & \\
& Between Groups & 10.184 & 4 & 2.546 & & \\
& Within Groups & 47.472 & 95 & .500 & & \\
\hline
\end{tabular}

Note. Significant at the 0.05 level.

\section{Discussion}

The study aimed to investigate the behaviour of consumers regarding pop-up ads. The study formulated four hypotheses regarding the impact of participants demographic characteristics upon their opinion about pop-up ads. The majority of the participants of this study were females belonging to the age group 36-55 years. Most of the participants had a monthly income of more than 10,000 Saudi riyals. The social media application majorly used by participants was Snapchat, and the majority of them spend 4 hours a day on different social media platforms. The study findings also indicated that participants strongly disagreed with the statement, "I always look for a way to keep up with pop-up ads".

The participants disagreed with the statement' trust products that advertise in pop-up ads,' this finding of the current study is in line with the findings of Le and Vo (2017), which shows that most people dislike pop-up ads. Still, fewer people dislike brands that use pop-up ads. Furthermore, people also disagree with the statement, 'I find the pop-up ads fun' it is supported by Liu, Liang and Liu (2019) study, which stated that there is a negative attitude of consumers towards pop-up ads and other studies Harms et al. (2019); Karivawasam and Wigley (2017) revealed that pop-up ads have more sense of annoyance and anger than any another advertisement. In addition, Le and Vo (2017), in a comparative study on the consumer attitude towards different advertisement formats, consider pop-up ads as least entertaining than the banner and in-line ads, which supports the study disagreement of participants on the statement 'the content that appears in the ad is very attractive'.

The results show only a significant difference in monthly income, whereas gender, age, and educational level did not significantly differ in their opinion about pop-up ads. In contrast, Krushali et al. (2021) study show that females are keen to observe the positive effects of pop-up ads than males. Moreover, their study also showed that females like pop-ups in terms of price comparability and product availability in the offseason. This finding is not in line with the current study results, which showed that gender had no significant difference in participants' opinions about pop-up ads. Furthermore, the recent research using the ANOVA test also finds no significant difference in educational level. In contrast, age group and monthly income significantly differ in participants' opinions about pop-up ads.

\section{Study Limitations}

The study has a number of limitations firstly, the small sample size of the study; secondly, it is region restricted; therefore, the results cannot generalise. Thirdly, this study only focuses on the demographic characteristics of the 
participants. Lastly, it only investigated the perceptions about pop-ups on social media platforms.

\section{Conclusion and Future Recommendations}

Pop up ads are often viewed as a necessary evil of the World Wide Web, but the research from the last twenty years backs up the common assumptions about them: they are irritating to internet users. The current study finds that consumers' overall perception is not positive towards pop-ups and find them to be annoying. Future studies can focus on conducting comparative studies about users' views in the East and the West about pop-ups. Moreover, studies can include other factors other than demographics that can impact users' perceptions towards pop-ups. Lastly, research can involve other forms of online advertisements such as banner ads, in-line ads, floating ads, etc., and on different online forums apart from social media platforms.

\section{Acknowledgement}

The author is very thankful to all the associated personnel in any reference that contributed in/for the purpose of this research.

\section{References}

Abbasi, A. Z., Rehman, U., Hussain, A., Ting, D. H., \& Islam, J. U. (2021). The impact of advertising value of in-game pop-up ads in online gaming on gamers' inspiration: An empirical investigation. Telematics and Informatics, 62, 101630. https://doi.org/10.1016/j.tele.2021.101630

Chaffey, D. (2020, April 17). Global social media research summary 2020. Retrieved from https://www.smartinsights.com/social-media-marketing/social-media-strategy/new-global-social-media-rese $\operatorname{arch} /$

Chan, A., Dodd, J., \& Stevens, R. (2004). The efficacy of pop-ups and the resulting effect on brands-A white paper by bunnyfoot Universality. White Paper.

Chatterjee, P. (2008). Are Unclicked Ads Wasted? Enduring Effects of Banner and Pop-Up Ad Exposures on Brand Memory and Attitudes. Journal of Electronic Commerce Research, 9(1).

Chi, H.-H. (2011). Interactive Digital Advertising VS. Virtual Brand Community: Exploratory Study of User Motivation and Social Media Marketing Responses in Taiwan. Journal of Interactive Advertising, 12, 44-61. https://doi.org/10.1080/15252019.2011.10722190

Chiu, Y.-P., Lo, S.-K., \& Hsieh, A.-Y. (2017). How Colour Similarity Can Make Banner Advertising E ective: Insights from Gestalt Theory. Behaviour \& Information Technology, 36(6), 606-619. https://doi.org/10.1080/0144929X.2016.1267264

Cho, C. H., \& Park, J. S. (2019). Introduction to the special issue: New trends in digital and social media advertising. https://doi.org/10.1080/02650487.2019.1644137

Courbet, D., Fourquet-Courbet, M. P., Kazan, R., \& Intartaglia, J. (2014). The long-term effects of e-advertising: The influence of internet pop-ups viewed at a low level of attention in implicit memory. Journal of Computer-Mediated Communication, 19(2), 274-293. https://doi.org/10.1111/jcc4.12035

Cox, S. A. (2010). Online Social Network Member Attitude Toward Online Advertising Formats. MA thesis, The Rochester Institute of Technology.

Diao, F., \& Sundar, S. S. (2004). Orienting response and memory for web advertisements: Exploring effects of pop-up window and animation. Communication Research, 31(5), 537-567. https://doi.org/10.1177/0093650204267932

Edwards, S. M., Li, H., \& Lee, J. H. (2002). Forced exposure and psychological reactance: Antecedents and consequences of the perceived intrusiveness of pop-up ads. Journal of Advertising, 31(3), 83-95. https://doi.org/10.1080/00913367.2002.10673678

Hsieh, A. Y., Lo, S. K., Chiu, Y. P., \& Lie, T. (2020). Do not allow pop-up ads to appear too early: Internet users' browsing behaviour to pop-up ads. Behaviour \& Information Technology, 1-10. https://doi.org/10.1080/0144929X.2020.1784282

IAB. (2017). Interactive Advertising Bureau. Retrieved August 24, 2021, from http://www.iab.net

Kariyawasam, K., \& Wigley, S. (2017). Online Shopping, Misleading Advertising and Consumer Protection. Information \& Communications Technology Law, 26(2), 73-89. https://doi.org/10.1080/13600834.2017.1289835

Katuwandeniya, I. M., \& Abeywardana, A. R. S. (2019). Web Users' Attitude Toward Pop-Up Advertisements in 
Western Province of Sri Lanka. Review of Behavioral Aspect in Organizations and Society, 1(2), 149-158. https://doi.org/10.32770/rbaos.vol1149-158

Keem, J. S., \& Lee, S. (2018). A study on consumers' experiences and avoidances of mobile shopping application advertisements. Journal of Global Fashion Marketing, 9(2), 148-160. https://doi.org/10.1080/20932685.2018.1432406

Kemp, S. (2021, February 11). Digital in Saudi Arabia: All the Statistics You Need in 2021. Data Reportal Global Digital Insights. Retrieved October 28, 2021, from https://datareportal.com/reports/digital-2021-saudi-arabia

Krushali, S., Jojo, N., \& Manivannan, A. S. (2018). Cognitive marketing and purchase decision with reference to pop up and banner advertisements. The Journal of Social Sciences Research, 4(12), 718-735.

Le, T. D., \& Vo, H. (2017). Consumer attitude towards website advertising formats: A comparative study of banner, pop-up and in-line display advertisements. International Journal of Internet Marketing and Advertising, 11(3), 202-217. https://doi.org/10.1504/IJIMA.2017.085654

Li, C., \& Meeds, R. (2005). Different forced-exposure levels of internet advertising: An experimental study on pop-up ads and interstitials (p. 200). In American Academy of Advertising. Conference. Proceedings. American Academy of Advertising.

Liu, W., Liang, X., \& Liu, F. (2019). The Effect of Webpage Complexity and Banner Animation on Banner Effectiveness in a Free Browsing Task. International Journal of Human-Computer Interaction, 35(13), 1192-1202. https://doi.org/10.1080/10447318.2018.1516843

Maina, M. (2021). Impact of Digital Marketing on Consumer Purchase Behavior among The Students of Bbit at Riara University. Doctoral dissertation.

Mäkinen, L. (2019). In the age of streaming services, how can advertisers connect with and influence consumer behaviour of younger audiences?

Mbugua, P., \& Ndavi, P. (2021). Effectiveness of Pop-Up Advertisements as Advertising Tools: The Case of the Co-operative University of Kenya. African Journal of Co-Operative Development and Technology, 6(1), 11-17. Retrieved from https://journals.cuk.ac.ke/index.php/12/article/view/41

McCoy, S., Everard, A., Galletta, D., \& Polak, P. (2004). A study of the effects of online advertising: A focus on pop-up and in-line ads. SIGHCI 2004 Proceedings, 11, 71-77. Raosoft. Retrieved from http://www.raosoft.com/samplesize.html

Susil, K. S. (2018). Attractiveness of Online Advertisement - A study on online buyers in engineering students. IOSR Journal of Business and Management (IOSR-JBM), 20(1).

Szalonka, K., Sadowa, A., Wicka, A., \& Wicki, L. (2020). E-Commerce Purchasing Behaviour and the Level of Consumers' Income in Poland and Great Britain. European Research Studies, 23(2), 552-568. https://doi.org/10.35808/ersj/1841

Thilina, D. K., Guruge, M. C. B., \& Nanayakkara, N. W. O. K. D. S. P. (2020). A Descriptive Analysis on Digital Behaviour of Young Adults in Sri Lanka. International Journal of Business and Management Invention (IJBMI), 9(6), 58-67.

Varghese, B. A., \& Chitra, D. S. (2020). The Role of Online Advertisement on Customer Attitude - A Study. PalArch's Journal of Archaeology of Egypt/Egyptology, 17(6), 2788-2794.

Wang, L., Ampiah, F., Xu, L., \& Wang, X. (2014, November). The influence of pop-up advertising on consumer purchasing behavior (pp. 217-220). In 2014 International Conference on Mechatronics, Electronic, Industrial and Control Engineering (MEIC-14). Atlantis Press. https://doi.org/10.2991/meic-14.2014.49

Wegert, T. (2002). Pop-up ads, part 1: good? Bad? Ugly. Retrieved July 9, 2004, from $\mathrm{https}: / / \mathrm{www}$.theatlantic.com/technology/archive/2014/08/advertising-is-the-internets-original-sin/376041/?s ingle_page $=$ true

Wijaya, V., \& Yulianti, N. M. D. R. (2020). Pop Up Ads Affecting Buying Decision Mediated by Purchase Intention in Online Marketplace (Lazada) in Denpasar. TIERS Information Technology Journal, 1(1). Retrieved from http://journal.undiknas.ac.id/index.php/tiers/article/view/2479 


\section{Copyrights}

Copyright for this article is retained by the author, with first publication rights granted to the journal.

This is an open-access article distributed under the terms and conditions of the Creative Commons Attribution license (http://creativecommons.org/licenses/by/4.0/). 